\title{
Biological Control of Listeria monocytogenes in silage
}

\author{
JA Mayer ${ }^{1}$, RJ Merry 2, HAS Epton 1, DC Sigee ${ }^{1}$ \\ 'School of Biological Sciences, 1.800 Stopford Building, University of Manchester, Oxford Road, \\ Manchester M13 9PT ; 21.G.E.R., Plas Gogerddan, Dyfed, SY23 3EB, UK
}

The pathogen Listeria monocytogenes is able to survive and grow in silage under certain conditions and therefore presents a health hazard to farm workers and ruminants consuming this feed.

In a research program designed to develop biocontrol measures, forty-six lactic acid bacteria antagonistic towards Listeria were selected by in vitro testing. Cell-free extracts were prepared from corresponding spent broths and tested in a well-diffusion assay (Schillinger and Lucke, 1989, Appl and Env Microbiol, 55, 1901-1906) to assess their ability to inhibit Listeria monocytogenes strain $4 \mathrm{~b}$. Antagonism was determined by the presence of a clear zone around the well cut in a Listeria lawn, with measurements being taken from the edge of the well to the edge of the clear zone. Neutralization of the cell-free extracts eliminated the inhibition of Listeria where it was solely due to $\mathrm{pH}$. Nine out of the forty-six isolates retained antagonistic activity after neutralization indicating that in these cases it was due to other products such as bacteriocins. The zone type as well as zone size varied in these tests : Isolates obtained from ensiled Cocksfoot (Dactylis glomerata) cv Cambria (Cam isolates) gave very clear zones with precise edges whereas isolates obtained from ensiled Timothy ( Phleum pratense) $\mathrm{cV}$ Kempe (T-D isolates)gave less clear zones with diffuse outer edges.

Cell-free extracts from two Lactobacillus isolates, Cam 2 and T5D 19 (results from well- diffusion assay in table) were tested against Listeria monocytogenes $4 b$ in a model silo system (Donald et al, 1993, Letts Appl Microbiol, 17, 253-255). The system aliowed the intermittent infusion of low, controlled levels of oxygen $(0.25 \%)$ to support the growth of Listeria. Late cut perennial ryegrass $\mathrm{cv}$ S35 (October) with a dry matter content of $22 \%$ was used in the experiment to provide a model for bale silage which is often made from a relatively poor quality herbage resulting in restricted fermentation and is thus susceptible to Listeria contamination.

All herbage was inoculated with the indicator strain Listeria monocytogenes $4 b$ and then four different treatments imposed prior to ensiling. Aliquots $(50 \mathrm{~g})$ of herbage were sprayed with Cam 2 cell-free extract, T5D19 cell-free extract, boiled Cam 2 cell-free extract or sterile distilled water as an untreated control. The silage was monitored for the presence of Listeria monocytogenes $4 b$, lactic acid bacteria, enterobacteria and fungi; $\mathrm{pH}$, lactate concentration and final dry matter were also recorded.

After 14 days the silage $\mathrm{pH}$ had fallen slowly for all treatments to ca 4.9 and preliminary results suggest that Listeria monocytogenes $4 b$ populations were lower in silage treated with Cam 2 cell-free extract.

These experiments indicate the potential for biocontrol of Listeria in silage through use of these strains of homofermentative lactobacilli as silage inoculants.

\begin{tabular}{lcc}
\hline Isolate & Clearing zone $(\mathrm{mm})$ untreated $(\mathrm{se})$ & Clearing zone $(\mathrm{mm})$ neutralized $(\mathrm{se})$ \\
\hline CAM 2 & $3.58(0.83)$ & $2.46(0.60)$ \\
T5D19 & $3.95(0.75)$ & $1.37(0.22)$
\end{tabular}

